DOI: $10.1515 /$ plass-2018-0013

\author{
Mehdi Aghighi Shahverdi ${ }^{1}$, Heshmat Omidi ${ }^{2 *}$
}

${ }^{1}$ Faculty of Agriculture, Shahed University, Tehran, Iran;

${ }^{2}$ Agricultural College and Medicinal Plant Research Center, Shahed University, Tehran, Iran; Corresponding author's e-mail: heshmatomidi@yahoo.com; omidi@shahed.ac.ir

\title{
DETERMINATION OF OPTIMUM CONCENTRATION AND TIME PRIMING OF STEVIA SEED WITH BORIC ACID $\left(\mathrm{H}_{3} \mathrm{BO}_{3}\right)$ MICRONUTRIENT
}

\begin{abstract}
S
In order to determine anoptimal duration and concentration of priming of stevia seed with boric acid for improving germination, an experimental factorial completely randomized design with three replications was conducted in the laboratory of Seed Science and Technology, Shahed University of Tehran in 2015. The first factor was different concentrations of boric acid (zero, $0.5,1,1.5$ and 2 percent) and the second factor of priming time $(0,8,16,24$ and 32 hours). Effects of concentration and duration of priming with Boric acid was significant on germination percentage, germination mean time, germination rate, germination energy, germination uniformity, germination mean daily, germination daily rate, germination value, seedling length and seed vigor index. The highest germination percentage, germination rate, germination energy, germination mean daily germination value and seed vigor index was 24 hours priming and the highest germination percentage, germination rate, germination potential, germination value and seed vigor index in priming of $2 \%$ Boric acid were obtained. Germination uniformity highest in 24 hours at $1 \%$ concentration priming of boric acid (5.51). Seedling length in 24 hours at $1.5 \%$ concentration priming with boric acid was highest average $1.02 \mathrm{~cm}$. Generally Stevia seed priming with boric acid for 24 hours at concentrations of 1.5 to 2 percent had positive effects on germination indexes and seedling growth.
\end{abstract}

Key words: boron, germination, micronutrients, nutripriming, seed vigor

Abbreviations

$$
\begin{aligned}
& \text { GP — germination percentage } \\
& \text { GR — germination rate } \\
& \text { GU — germination uniformity } \\
& \text { DGS — daily germination speed } \\
& \text { SL — seedling length }
\end{aligned}
$$

$$
\begin{aligned}
& \text { MGT - mean germination time } \\
& \text { GE - germination energy } \\
& \text { MDG - mean daily germination } \\
& \text { GV — germination value } \\
& \text { SVI — seedling vigor index }
\end{aligned}
$$

Communicated by Grzegorz Żurek 


\section{INTRODUCTION}

There are 17 essential elements for idealistic growth and development of plants that are divided into macro- and microelements. In addition to their roles as a cofactor in enzymes and redox reactions, Micronutrient elements have several important and vital actions in plants (Farooq et al., 2012). More importantly, micronutrients are involved in physiologically key reactions of photosynthesis and respiration pathways (Mengel et al., 2001), and lack of those elements limits these vital processes and subsequently reduce productivity. For example, boron deficiency can decrease wheat (Rerkasem and Jamjod, 2004) Chickpea (Johnson et al., 2005) and lentil (Srivastava et al., 2000) productivity. Boric acid is one of the necessary elements for normal growth and development of several different plants (Abdollahi et al., 2012). Reduced productivity because of boron deficiency could be the result of severe disturbance in metabolic reaction involved with this element, like nucleic acid, carbohydrate, proteins and indole acetic acid metabolism, cell wall biosynthesis, phenol metabolism, and preserving plasma membrane integrity and function (Tanaka and Fujiwar, 2008). Functionally boron is related to several different process such as using calcium, cell division, flowering and fruiting, nitrogen and carbohydrate metabolism, disease tolerance, water relationships and specific catalytic reactions (Farooq et al., 2012).

Concentration of priming solution is one of the important factors in seed priming by boron element. For example, research on seed priming with boric acid solution (concentration of 2-20 mM) has been conducted in Russia, and both negative (reduction) and positive (increasing) effects had been reported on germination parameters of different crops like rapeseed, sunflower, soybean, sugar beet, alfalfa, wheat and barley (Shorrocks, 1997 ; Rehman et al., 2012). Significant improvement of germination and primary growth of papaya seedling observed when the seeds were primed with boron solution $(2 \mathrm{mg} / \mathrm{L})$ for 6 hours (Deb et al., 2010).

There are different types of priming which being used in priming experiments and they include hydro-, halo-, osmo-, thermos- and hormone priming, and there are different reports on this matter with different plants and different researchers (McDonald, 2000; Iqbal et al., 2012; Rehman et al., 2012; Mirshekari, 2012). Nutri-priming is a relatively new method in which seeds are primed by using micro and macronutrients, has been recently focused on (Rehman et al., 2012; Mirshekari, 2012). Nutrients as fertilizers were used by different methods such as soil application, with irrigation water or foliar fertilization (Rober, 2008). Using nutrients as a seed treatment by coating and seed priming are other methods that could be advantageous (Farooq et al., 2012). Seed priming by using micronutrients (enrichment) has been reported as one of the best ways to beat micronutrient deficiency (Harris et al., 1999). Seed priming with micronutrient elements results in higher rate of water adsorption and metabolism and germination of seeds which consequences could be seen in higher rate of germination, improvement of seedling establishment, higher resistance against stress and pest, and finally higher productivity (Memon et al., 2013). 
Stevia (Stevia rebaudiana Bertoni), is a perennial, herbal species of Acetracea family (Hossein et al., 2008). Stevia plant has a high sweetening property because of steviol glycosides (Singh and Rao, 2005) which firstly are not absorbed by digestive system and so diabetics can use it freely, and secondly, it is not caloric, so it is adequate for fat people who have to care about their daily calorie. Because of its self-incompatibility, stevia pollinate by wind and insects, so the percentage of fertilized flowers and liable is low in this plant and the seeds have low germination percent (Liopa-Tsakalidi et al., 2012). Although, presented studies shows that there is no agreement for the reason of low germination ability of stevia seeds, some researchers introduce self-incompatibility as a reason of weak stevia germination (Oddone, 1997; Purohit, 2008), while some others report that there are no self-incompatibility in this plant (Goettemoeller and Ching, 1999). By the way, weak germination in this plant is an obstacle against large scale planting and results in scarce a high price of effective metabolite of this plant (Raji et al., 2015). In this research, we aim to study the priming with boric acid effects on germination parameters of stevia seeds, and determining best time and favorable concentration of priming solution of this micronutrient element.

\section{MATERIAL AND METHOD}

This experiment were conducted in the Seed Science and Technology Laboratory of Agriculture college of Shahed University, using factorial experiment based on a completely randomized design with three replications, in order to determine the adequate time and concentration for stevia seed priming with boric acid in 2015-2016. Priming time and concentration of boric acid solution were $0,8,16,24$ and 32 hours and $0,0.5,1,1.5$ and 2 percent respectively. Stevia seeds (Bertoni cultivar) which were produced in the agriculture year of 2013 -2014 were purchased from an Indian company (Global Horticulture Products) and disinfected with sodium hypochlorite $10 \%$ for $3 \mathrm{~min}$ and the rinsed with distilled water. At the end of priming process, the seeds were washed with distilled water and dried for 24 hours in lab. In every petri dish, 25 seeds were placed on Watman paper, the $3 \mathrm{ml}$ water were added and to prevent water evaporation the cover of the petri dishes were fixed and closed by parafim. Seed germination process in growth chamber was controlled on $23 \pm 2^{\circ} \mathrm{C}$, photoperiod of $18 / 6$ (day/night) and relative humidity of $70 \pm 5 \%$ (Raina et al., 2013). Counting of germinated seeds starts from day 2 in a specific hour (Liopa-Tsakalidi et al., 2012) and in the end of the experiment, after 11 days, germination percentage (Liopa-Tsakalidi et al., 2012) germination speed (Pagter et al., 2009), mean germination time (Ellis and Roberts, 1981), average germination per day (Hoogenboom and Peterson, 1987), daily germination rate (Steohanie et al., 2005), germination value index (Ghasemi-Golozani and Dalil, 2011), germination energy (Panwar and Bhardwaj, 2005) and seed vigor index (Biradar et al., 2007) were calculated according to the equations in Table 1. Data analysis and comparison of evaluated parameters were done by SAS 9.1 and Duncan multiple range test at $5 \%$, respectively. 
The computing relation of the parameters studied in the experiment

\begin{tabular}{ll}
\hline \multicolumn{1}{c}{ Parameters } & \multicolumn{1}{c}{ Computing relations } \\
\hline Germination Percentage & $\mathrm{GP}=(\mathrm{N} \times 100) / \mathrm{M}$ \\
Germination Rate & $\mathrm{GR}=\sum \mathrm{N}_{\mathrm{i}} / \mathrm{T}_{\mathrm{i}}$ \\
Mean Germination Time & $\mathrm{MGT}=\sum\left(\mathrm{N}_{\mathrm{i}}\right) / \sum \mathrm{N}$ \\
Mean of Daily Germination & $\mathrm{MDG}=\mathrm{N} / \mathrm{T}$ \\
Daily Germination Speed & $\mathrm{DGS}=1 / \mathrm{MDG}$ \\
Germination Value & $\mathrm{GV}=\mathrm{GP} \times \mathrm{MDG}$ \\
Germination Energy & $\mathrm{GE}=\mathrm{M}_{\mathrm{cgr}} /\left(\mathrm{N}_{\mathrm{i}} \times 100\right)$ \\
Seed Vigor Index & $\mathrm{SVI}=\mathrm{GP} \times \mathrm{Mean}(\mathrm{SL})$ \\
\hline
\end{tabular}

$N=$ sum of germinated seeds at the end of the experiment, $M=$ total planted seeds, $T=$ period of germination, $T i=$ number of days after germination, $\mathrm{n}=$ number of germinated seeds in $T i, M c g r=$ maximum cumulative germination percentage, $N i=$ Total seeds sown, $S L=$ Seedling Length

\section{RESULTS AND DISCUSSION}

\section{Germination percentage}

The effect of time period and concentration of boric acid on stevia seeds germination were significant in $\mathrm{P} \leq 0.01$ (Table 2). The highest rate of germination among the priming times and different concentration of acid boric, was observed for priming time for 24 hours and the concentration of $2 \%$ with the average of 42.66 and 44 percent, respectively (Table 3 and 4). Seed priming with boric acid $2 \%$ increase germination rate by 35.72 in comparison with control in stevia seeds. There was a significant and positive correlation at $\mathrm{P} \leq 0.01$ between germination percentage and germination rate, germination energy, seedling length, germination value index, germination uniformity and germination value (Table 5). Together, these results indicate that increasing in seed germination percent will lead to improvement of seed germination parameters in this plant, and finally will result in seed vigor index and germination energy . In agreement with our data, Bayat et al (2014) showed significant and positive correlation between seed germination and seedling length, seed vigor, germination energy and germination rate. Mirshekari (2012) reported that Anethum graveolens L. seed germination with acid boric micronutrient have a significant effect on seed germination and boric acid $1.5 \%$ has the highest rate of germination in this plant. It should be noted that much higher concentration and longer times for seed priming with micronutrients have negative effects on seed germination parameters (Mirshekari, 2012). 
Summary of variance analysis for effect of times $(0,8,16,24$ and $32 \mathrm{~h})$ and concentration

$(0,0.5,1,1.5$ and $2 \%)$ of priming with boric acid $\left(\mathrm{H}_{3} \mathrm{BO}_{3}\right)$ on Stevia (Stevia rebaudiana Bertoni) seed germination indices and growth seedling

\begin{tabular}{lcccccr}
\hline \multicolumn{1}{c}{ Sources of variance } & DF & GP & MGT & GR & GE & GU \\
\hline Priming Time (PT) & 4 & $283.94 * *$ & $2.83^{* *}$ & $2.32^{* *}$ & $0.00007^{* *}$ & $1.21^{* *}$ \\
Priming Concentration (PC) & 4 & $579.94 * *$ & $0.33^{*}$ & $1.97 * *$ & $0.00018^{* *}$ & $1.49^{* *}$ \\
PT $\times$ PC & 16 & $3.81 \mathrm{~ns}$ & $0.12 \mathrm{~ns}$ & $0.08 \mathrm{~ns}$ & $0.00001 \mathrm{~ns}$ & $0.17^{* *}$ \\
Experimental error & 48 & 7.21 & 0.09 & 0.05 & 0.000009 & 0.002 \\
Coefficient of variation [\%] & & 7.41 & 6.16 & 11.08 & 22.09 & 1.11 \\
\hline \multicolumn{1}{c}{ Sources of variance } & $\mathrm{DF}$ & $\mathrm{MDG}$ & $\mathrm{DGS}$ & $\mathrm{GV}$ & $\mathrm{SL}$ & $\mathrm{SVI}$ \\
\hline Priming Time(PT) & 4 & $2.34 * *$ & $0.0043^{* *}$ & $1.32^{* *}$ & $0.092^{* *}$ & $5501874.6^{* *}$ \\
Priming Concentration (PC) & 4 & $4.79 * *$ & $0.0006^{*}$ & $2.53 * *$ & $0.226^{* *}$ & $11216896^{* *}$ \\
PT $\times$ PC & 16 & $0.03 \mathrm{~ns}$ & $0.0002 \mathrm{~ns}$ & $0.02 \mathrm{~ns}$ & $0.001 * *$ & $60269.3 \mathrm{~ns}$ \\
Experimental error & 48 & 0.05 & 0.0001 & 0.03 & 0.0006 & 52007.1 \\
Coefficient of variation [\%] & & 7.41 & 6.32 & 14.83 & 3.43 & 7.96 \\
\hline
\end{tabular}

(GP - Germination percentage, MGT - Mean Germination of time, GR - Germination rate,

GE - Germination energy, GU - Germination uniformity, MDG - Mean daily germination,

DGS — Daily germination speed, GV — Germination value, SL — seedling length, SVI — Seedling vigor index)

\section{Mean germination time}

Base on analysis of variance, the priming time and priming concentration of seeds with boric acid have a significant effect on average time required for germination (Table 2). The highest and lowest required time for germination observed in 32 and 8 hours of priming, respectively (5.65 and 4.50, respectively, Table 3). Among different concentration of boric acid, the concentration of $1 \%$ have the highest required time for germination which belong to the same group as 1.5 and 2 percent, but have a significant level of difference with the others (Table 4). Average required time for germination has negative correlation and significant difference with germination speed and daily germination speed at $\mathrm{P} \leq 0.01$ (Table 5). Seed priming with boron (nutri-priming) have advantageous effects on seed germination, mean time of germination, seedling vigor index and seedling length (Memon et al., 2013). 
Table 3

Mean comparison of stevia (Stevia rebaudiana Bertoni) seed germination indices under effect of different priming time with Boric acid $\left(\mathrm{H}_{3} \mathrm{BO}_{3}\right)$

\begin{tabular}{ccccc}
\hline Priming time $[\mathrm{h}]$ & GP & MGT [day] & GR [seed per day] & GE \\
\hline 0 & $31.46 \mathrm{~d}$ & $4.89 \mathrm{~b}$ & $1.84 \mathrm{c}$ & $0.012 \mathrm{c}$ \\
8 & $33.60 \mathrm{c}$ & $4.50 \mathrm{c}$ & $2.19 \mathrm{~b}$ & $0.012 \mathrm{c}$ \\
16 & $38.13 \mathrm{~b}$ & $4.80 \mathrm{~b}$ & $2.33 \mathrm{~b}$ & $0.014 \mathrm{~b}$ \\
24 & $42.66 \mathrm{a}$ & $4.73 \mathrm{~b}$ & $2.70 \mathrm{a}$ & $0.017 \mathrm{a}$ \\
32 & $35.20 \mathrm{c}$ & $5.65 \mathrm{a}$ & $1.72 \mathrm{c}$ & $0.013 \mathrm{bc}$ \\
\hline Priming time $[\mathrm{h}]$ & MDG & DGS & GV & SVI \\
\hline 0 & $2.86 \mathrm{~d}$ & $0.20 \mathrm{~b}$ & $0.93 \mathrm{~d}$ & $2135.5 \mathrm{e}$ \\
8 & $3.05 \mathrm{c}$ & $0.22 \mathrm{a}$ & $1.05 \mathrm{~cd}$ & $2539.20 \mathrm{~d}$ \\
16 & $3.46 \mathrm{~b}$ & $0.20 \mathrm{~b}$ & $1.36 \mathrm{~b}$ & $3029.87 \mathrm{~b}$ \\
24 & $3.87 \mathrm{a}$ & $0.21 \mathrm{~b}$ & $1.69 \mathrm{a}$ & $3757.87 \mathrm{a}$ \\
32 & $3.20 \mathrm{c}$ & $0.17 \mathrm{c}$ & $1.15 \mathrm{c}$ & $2852.53 \mathrm{c}$ \\
\hline
\end{tabular}

In each column, means having at least one same letter, are not significantly different according to Duncan's multiple range test $(\mathrm{p} \leq 0.05)$. (GP - germination percentage, MGT - mean germination time,

GR - germination rate, GE — germination energy, MDG — mean daily germination, DGS — daily germination speed, GV - germination value, SVI - seedling vigor index)

Mean comparison of stevia (Stevia rebaudiana Bertoni) seed germination indices

Table 4 under effect of different priming concentration with boric acid $\left(\mathrm{H}_{3} \mathrm{BO}_{3}\right)$

\begin{tabular}{|c|c|c|c|c|}
\hline $\begin{array}{c}\text { Priming } \\
\text { concentration } \\
{[\%]}\end{array}$ & GP & $\begin{array}{l}\text { MGT } \\
\text { [day] }\end{array}$ & $\begin{array}{c}\text { GR } \\
\text { [seed per day] }\end{array}$ & GE \\
\hline 0 & $28.26 \mathrm{e}$ & $4.76 \mathrm{~b}$ & $1.69 \mathrm{~d}$ & $0.010 \mathrm{~d}$ \\
\hline 0.5 & $32.00 \mathrm{~d}$ & $4.78 \mathrm{~b}$ & $1.98 \mathrm{c}$ & $0.011 \mathrm{~cd}$ \\
\hline 1 & $37.06 \mathrm{c}$ & $5.12 \mathrm{a}$ & $2.09 \mathrm{c}$ & $0.013 \mathrm{c}$ \\
\hline 1.5 & $39.73 \mathrm{~b}$ & $4.94 \mathrm{ab}$ & $2.38 \mathrm{~b}$ & $0.016 \mathrm{~b}$ \\
\hline 2 & $44.00 \mathrm{a}$ & $4.97 \mathrm{ab}$ & $2.64 \mathrm{a}$ & $0.018 \mathrm{a}$ \\
\hline $\begin{array}{c}\text { Priming } \\
\text { concentration } \\
{[\%]} \\
\end{array}$ & MDG & DGS & GV & SVI \\
\hline 0 & $2.56 \mathrm{e}$ & $0.21 \mathrm{a}$ & $0.74 \mathrm{e}$ & $1680.80 \mathrm{~d}$ \\
\hline 0.5 & $2.90 \mathrm{~d}$ & $0.21 \mathrm{a}$ & $0.95 \mathrm{~d}$ & $2318.67 \mathrm{c}$ \\
\hline 1 & $3.36 \mathrm{c}$ & $0.19 \mathrm{~b}$ & $1.26 \mathrm{c}$ & $2992.27 \mathrm{~b}$ \\
\hline 1.5 & $3.61 \mathrm{~b}$ & $0.20 \mathrm{ab}$ & $1.45 \mathrm{~b}$ & $3590.40 \mathrm{a}$ \\
\hline 2 & $4.00 \mathrm{a}$ & $0.20 \mathrm{ab}$ & $1.78 \mathrm{a}$ & $3729.87 \mathrm{a}$ \\
\hline
\end{tabular}

In each column, means having at least one same letter, are not significantly different according to Duncan's multiple range test $(\mathrm{p} \leq 0.05)$. (GP - germination percentage, MGT - mean germination time, GR - germination rate, GE - Germination energy, MDG - mean daily germination, DGS - daily germination speed, $\mathrm{GV}$ - germination value, SVI - Seedling vigor index) 
Correlation assessment among stevia (Stevia rebaudiana Bertoni) seed germination indices and seedling growth under different concentration and time of priming with boric acid $\left(\mathrm{H}_{3} \mathrm{BO}_{3}\right)$

\begin{tabular}{|c|c|c|c|c|c|c|c|c|c|c|}
\hline Indices & 1 & 2 & 3 & 4 & 5 & 6 & 7 & 8 & 9 & 10 \\
\hline 1-GP & 1 & & & & & & & & & \\
\hline 2-MGT & $0.09 \mathrm{~ns}$ & 1 & & & & & & & & \\
\hline 3-GR & $0.85^{* *}$ & $-0.41 * *$ & 1 & & & & & & & \\
\hline 4-GE & $0.99 * *$ & $0.09 \mathrm{~ns}$ & $0.85^{* *}$ & 1 & & & & & & \\
\hline 5-SL & $0.83^{* *}$ & $0.20 \mathrm{~ns}$ & $0.65^{* *}$ & $0.83 * *$ & 1 & & & & & \\
\hline 6-SVI & $0.96^{* *}$ & $0.14 \mathrm{~ns}$ & $0.80 * *$ & $0.96 * *$ & $0.93 * *$ & 1 & & & & \\
\hline 7-GU & $0.72 * *$ & $-0.17 \mathrm{~ns}$ & $0.77 * *$ & $0.72 * *$ & $0.68^{* *}$ & $0.73 * *$ & 1 & & & \\
\hline 8-MDG & $0.99 * *$ & $0.09 \mathrm{~ns}$ & $0.85^{* *}$ & $0.99 * *$ & $0.83 * *$ & $0.96^{* *}$ & $0.72 * *$ & 1 & & \\
\hline 9-DGS & $-0.11 \mathrm{~ns}$ & $-0.99 * *$ & $0.39 * *$ & $-0.11 \mathrm{~ns}$ & $-0.22 \mathrm{~ns}$ & $-0.16 n s$ & $0.15 \mathrm{~ns}$ & $-0.11 \mathrm{~ns}$ & 1 & \\
\hline 10-GV & $0.99 * *$ & $0.08 \mathrm{~ns}$ & $0.85^{* *}$ & $0.99 * *$ & $0.79 * *$ & $0.95 * *$ & $0.71^{* *}$ & $0.99 * *$ & $-0.11 \mathrm{~ns}$ & 1 \\
\hline
\end{tabular}

$\mathrm{ns}, *$ and $* *$ - non-significant, significant at $5 \%$ and $1 \%$ respectively

GP — germination percentage, MGT — mean germination time, GR - germination rate, GE - germination energy, GU — germination uniformity, MDG — mean daily germination, DGS — daily germination speed, GV — germination value, SL — seedling length, SVI — seedling vigor index

\section{Germination rate}

The effect of time and concentration of seed priming with boric acid on germination rate was significant at $\mathrm{P} \leq 0.01$ (Table 2). Seed priming with acid boric for 24 hours increase germination rate by approximately 33 percent in comparison with control (without priming, Table 3). Highest germination rate was observed for seed priming with acid boric $2 \%$ with average of 2.64 seed per day (Table 4). Except for mean time of germination, germination rate has positive and significant correlation with other treatments at $\mathrm{P} \leq 0.01$ (Table 5). Seed priming with micronutrients results in higher rate of water adsorption and consequently beginning of metabolism and seed germination which consequently produce higher germination rate (Rowse, 1995). Aghighi Shahverdi and Omidi (2015) reports that stevia seed priming for 24 hours with gibberellin hormone results in significant increase in germination rate and other germination parameters in the seeds of this plant.

\section{Germination energy}

According to the analysis of variance (Table 2) the effect of time period and the concentration of seed priming on Stevia seeds germination energy were significant at $\mathrm{P} \leq 0.01$. Highest germination energy was for 24 hours of seed priming (0.017) and the lowest germination energy was for control (without priming $=0$ hour) and 8 hours of seed priming (Table 3). Also, highest germination energy for stevia seeds was for boric acid $2 \%$ with mean of 0.018 , which show $44.44 \%$ increasing in germination energy in comparison to the control (Table 4). Germination energy is one of the most important parameters to evaluate quality and power of the seeds, and 
higher germination energy shows higher quality and power of the seeds (Bayat et al., 2015).

\section{Germination uniformity}

The effect of priming period, concentration and interplay between them on germination uniformity was significant (Table 2). Studies on the mean of interplay clearly indicate that highest germination uniformity was for combination of 24 hours of priming in boric acid $1 \%$, and the lowest rate of germination uniformity observed at priming for 0 and 32 hours in control concentration of boric acid (Fig. 1). Farooq et al. (2006) introduce improvement of $\alpha$-amylase activity ad increasing of soluble sugar as the reason for homogenous greening and germination of pretreated seeds of rice.

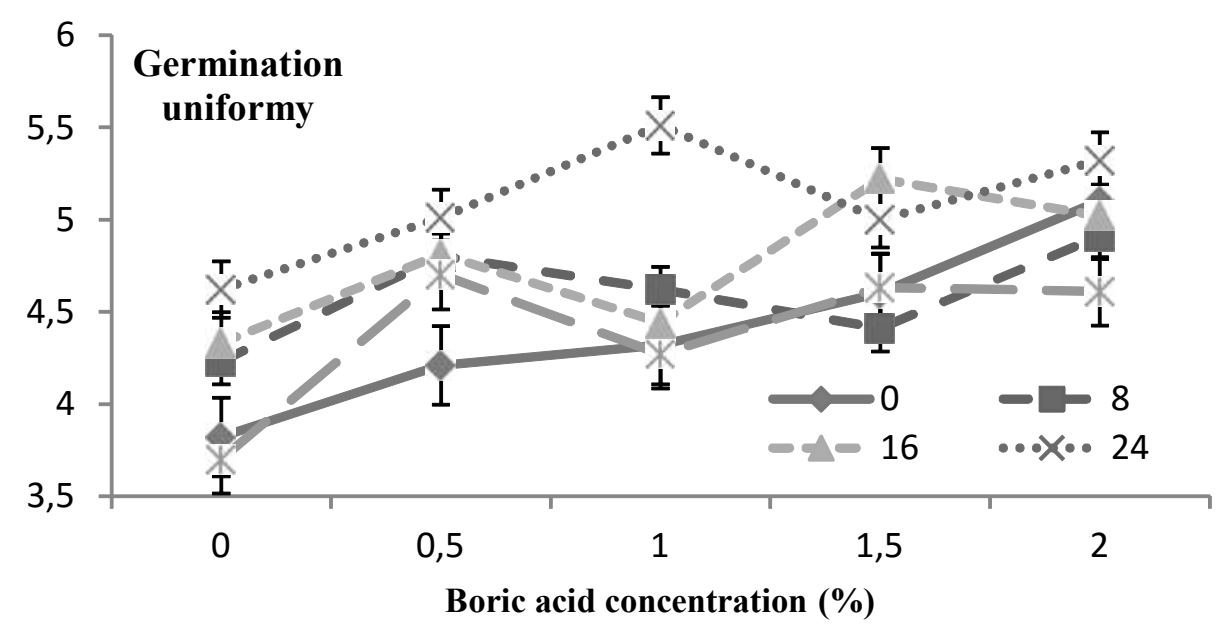

Fig. 1. Mean comparison of stevia seed germination uniformly in concentration $\times$ priming time interaction with boric acid $\left(\mathrm{H}_{3} \mathrm{BO}_{3}\right)$. Concentration levels $=0,0.5,1,1.5$ and 2 percentage

Time levels: $0,8,16,24$ and $32 \mathrm{~h}$

\section{Mean of daily germination}

The effect of time and concentration of priming on mean of daily germination was significant at $\mathrm{P} \leq 0.01$ (Table 2). Highest and lowest mean of daily germination was for 24 hours period priming and control (zero hour), respectively (Table 3). Among different concentration, the highest rate of it was observed for seed priming with boric acid $2 \%$, which, in comparison with control (concentration zero) show 36.5 increasing in mean of it (Table 4).

\section{Daily germination speed}

According to data analysis of variance (Table 2), the effect of priming time period and the concentration of acid boric were significant at $\mathrm{P} \leq 0.01$ and $\mathrm{P} \leq 0.05$, respectively. Highest speed of daily germination was at 8 hours seed priming with boric acid 
(Table 3). Also, except for concentration of $1 \%$ which has the lowest mean of daily germination speed, other concentration treatments have insignificant effect compare to each other on this parameter (Table 4). It is reported that low concentrations of boric acid which is involved with activation of enzymes like phosphatase, amylase and so on which are involved in starch metabolism, results in commence of metabolism in seeds and increase daily germination speed by this way (Memon et al., 2013).

\section{Germination value}

Data analysis results showed that the effect of time period and concentration of seed priming on germination value parameter for stevia seeds was statistically significant at $\mathrm{P} \leq 0.01$ (Table 2). Seed priming for 24 hours show highest value of seed germination, and the control time (without priming) had the lowest mean for this parameter (Table $3)$. Among the experimented concentrations, by increasing of concentration, statistically significant increase was observed for germination value parameter, so that the 0 and $2 \%$ concentration have the lowest and highest mean for this parameter (Table 4 ).

\section{Seedling length}

Results analysis of variance (Table 2 ) showed that the effect of time period, concentration and their interplay (priming time period $\times$ priming concentration) on seedling length was statistically significant at $\mathrm{P} \leq 0.01$. Comparing the mean of the effects of interplay (Fig. 2) showed that the longest $(1.02 \mathrm{~cm})$ and shortest $(0.44 \mathrm{~cm})$ seedling length observed for 24 hours seed priming with boric acid $1.5 \%$ and control (without priming), respectively. Material transport in primed seeds is high because of higher activity of enzymes involved in sucrose metabolism (sucrose synthase, invertase, sucrose phosphate synthase), so these seeds have higher biological power and germinate quicker and produce plumule and radicle, so clearly have higher seedling length (Kaur et al., 2005).

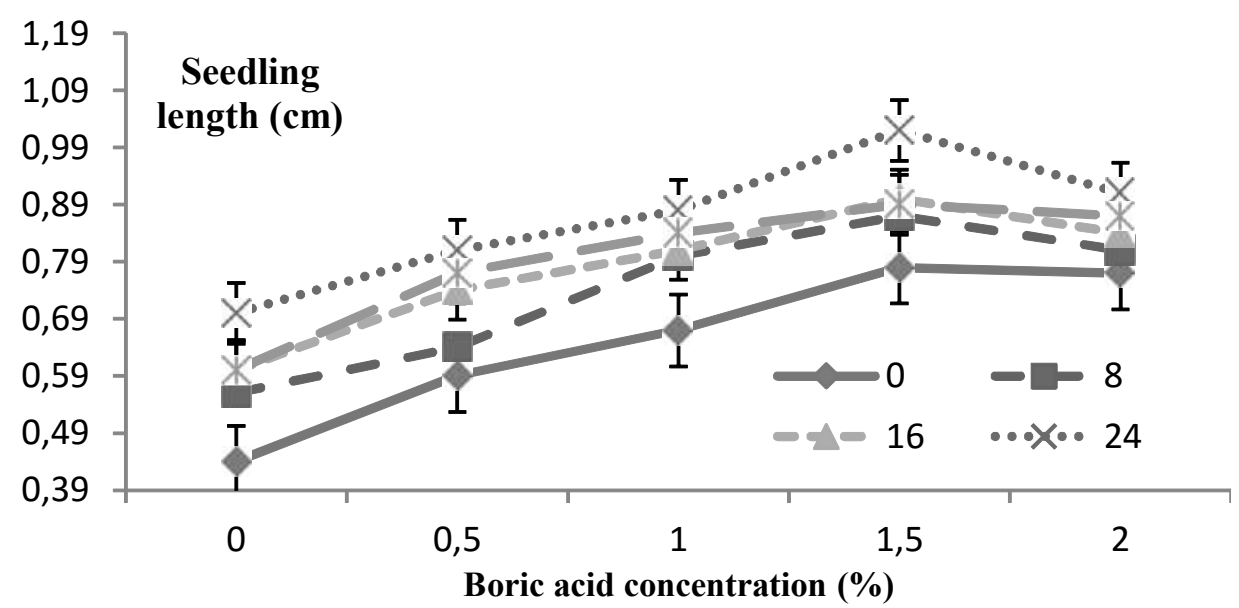

Fig. 2. Mean comparison of stevia seedling length in concentration $\times$ priming time interaction with boric acid $\left(\mathrm{H}_{3} \mathrm{BO}_{3}\right)$. Concentration levels $=0,0.5,1,1.5$ and 2 percentage, Time levels: $0,8,16,24$ and $32 \mathrm{~h}$ 


\section{Seed vigor index}

According to results, the effect of priming time period and boric acid concentration for priming on seed vigor index, was statistically significant at $\mathrm{P} \leq 0.01$ (Table 2). Among the priming periods, 24 hour of seed priming and control have the highest and lowest seed vigor index. Highest seed vigor index gained at boric acid concentration of 1.5 and $2 \%$ which was $53 \%$ higher than control (Table 4). Seed vigor index have a positive correlation and statistically significance at $\mathrm{P} \leq 0.01$ with germination percentage, germination speed, germination energy, seedling length, germination uniformity, mean daily germination and germination value (Table 5). The importance of seedling vigor for fast establishment and primary growth of medicinal plant in order to competence for receiving water, light and minerals were emphasized in the studies of Tabrizian and Osareh, 2007. Seed priming with boron micronutrients $\left(\mathrm{H}_{3} \mathrm{BO}_{3}\right)$ and iron $\left(\mathrm{FeSO}_{4}\right)$ resulted in increase of seed vigor index in Anethum graveolens $\mathrm{L}$. (Mirshekari, 2012).

\section{CONCLUSION}

Our results showed that stevia seeds react positively to priming with boric acid, and it improved and increased germination parameters in this plant. In order to enhance seed vigor index and percentage and speed of stevia seed germination, priming with boric acid 1.5 and 2 for 24 hours showed best result in this experiment.

\section{ACKNOWLEDGEMENTS}

This article is extracted from a Ph.D. thesis of the first author.

\section{REFERENCE}

Abbdillahi M., Eshghi S., Tafazzoli E., Moosavi N. (2012): Effects of Paclobutrazol, Boric acid and Zinc Sulfate on vegetative and reproductive growth of Strawberry cv. Selva. Journal Agriculture Science Technology. 14:357-363.

Aghighi Shahverdi M., Omidi H. (2015): Effect of hormone priming and hydro priming on germination of Stevia (Stevia rebaudiana Bertoni) under salt stress. Iranian of Seed Sciences and Research, [In Press]

Bayat M., Rahmani A., Amirnia R., Ramazani M. (2014): The effect of priming and duration of priming on germination indices and seedling characteristics_of Althaea Officinalis L. Iranian Journal of Seed Science and Technology, 4(1):73-82.

Biradar K.S., Salimath P.M., Ravikumar R.L. (2007): Genetic variability for seedling vigour, yield and yield components in local germplasm collections of Greengram (Vigna radiata (L.) wilczek), Karnataka Journal Agriculture Science, 20 (3): 608-609.

Deb P., Das A., Ghosh S.K., Suresh C.P. (2010): Improvement of seed germination and seedling growth of papaya (Carica papaya L.) through different pre-sowing seed treatments. Acta Hort.851: 313-316.

Ellis R.H., Roberts E.H. (1981): The quantification of ageing and survival in orthodox seeds. Seed Science and Technology, 9: 377-409.

Farooq M., Wahid A., Siddique K.H.M. (2012): Micronutrient application through seed treatments- a review. Journal of Soil Science and Plant Nutrition, 12: 125-142.

Farooq M., Basra S.M.A., Warraich E.A., Khaliq A. (2006): Optimization of hydro priming techniques for rice seed invigoration. Seed Science and Technology. 34: 529-534. 
Ghasemi gholozani K., Dalil B. (2011): Germination and seed vigor tests. Publications Jahad Daneshgahi Mashhad .

Goettemoeller J., Ching A. (1999): Seed germination in Stevia rebaudiana. In: Janick, J (eds) Perspectives on new crops and new uses. ASHS Press, Alexandria, VA. Pp: 510-511

Harris D., Joshi A., Khan P.A., Gothkar P., Sodhi P.S. (1999): On-farm seed priming in semiarid agriculture: Development and evaluation in maize, rice and chickpea in India using participatory Methods. Experimental Agriculture, 35: 15-29.

Hoogenboom G., Peterson C.M. 1987. Shoot growth rate of soybean as affected by drought stress. Agronomy Journal, 79:598-607.

Hossein M.A., Shamim Kabri A.M., Jahan T.A., Hassan M.N. (2008): Micro propagation of Stevia rebaudiana. International Journal of Sustainable crop production. 3:1-90.

Iqbal S., Farooq M., Nawaz A., Rehman A. (2012): Optimizing boron seed priming treatments for improving the germination and early seedling growth of wheat. Journal of Agriculture and Social Sciences, $8: 57-$ 61.

Johnson S.E., Lauren J.G., Welch R.M., Duxbury J.M. (2005): A comparison of the effects of micronutrient seed priming and soil fertilization on the mineral nutrition of chickpea (Cicer arietinum), lentil (Lens culinaris), rice (Oryza sativa) and wheat (Triticum aestivum) in Nepal. Exper. Agric. 41: 427-448.

Kaur S., Gupta A.K., Kaur N. (2005): Seed priming increase crop yield possibly by modulating enzymes of sucrose metabolism in chickpea. J. Agron. Crop Science. 191: 81-87.

Liopa-Tsakalidi A., Kaspiris G., Salahas G., Barouchas P. (2012): Effect of salicylic acid (SA) and gibberellic acid $\left(\mathrm{GA}_{1}\right)$ pre-soaking on seed germination of Stevia (Stevia rebaudiana) under salt stress. Journal of Medicinal Plants Research. 6: 416-423.

McDonald M.B. (2000): Seed priming. In M. Black, \& J. D. Bewley (Ed.). Seed Technology and Biological Basis, Black (Chapter 9, pp: 287-325). Sheffield Academic Press, England.

Memon N.N., Gandahi M.B., Pahoja V.M., Sharif N. (2013): Response of seed priming with Boron on germination and seedling sprouts of Broccoli. International Journal of Agriculture Science and Research. 3 (2):183-194.

Mengel K., Kirkby E.A., Kosegarten H., Appel T. (2001): Principles of Plant Nutrition. Kluwer Academic Publishers, Dordrecht, the Netherlands

Mirshekari B. (2012): Seed priming with iron and boron enhances germination and yield of dill (Anethum graveolens). Turkish Journal of Agriculture and Forestry, 36: 27-33.

Oddone B. (1997): How to Grow Stevia. Technical Manual. Guarani Botanicals, Pawtucket, CT.

Pagter M., Bragato C., Malagoli M., Brix H. (2009): Osmotic and ionic effects of $\mathrm{NaCl}$ and $\mathrm{Na}_{2} \mathrm{SO}_{4}$ salinity on Phragmites australis. Aquatic Botany, 90: 43-51.

Panwar P., Bhardwaj S.D. (2005): Handbook of practical forestry, Agrobios (INDIA), 191p.

Raina R., Bhandari S.K., Chand R., Sharma Y. (2013): Strategies to improve poor seed germination in Stevia rebaudiana, a low calorie sweetener. Journal of Medicinal Plants Research, 7:1793-1799.

Raji A.A., Mohammad B.O., Zarina B.Z. (2015): Acclimatized apparatus enhanced seed germination in Stevia rebaudiana Bertoni. International Journal of Biology, 7:28-34.

Rehman A., Farooq M., Cheema Z.A., Wahid A. (2012): Role of boron in leaf elongation and tillering dynamics in fine grain aromatic rice. J. Plant Nutr. 38 (3):338-354.

Rerkasem B., Jamjod S. (2004): Boron deficiency in wheat: a review. Field Crops Res 89: 173-186.

Rowse H.R. (1995): Drum priming: A non-osmotic method of priming seeds. Seed Sci Technol 24: 281- 294

Shorrocks V.M. (1997): The occurrence and correction of boron deficiency. Plant Soil, 193: 121-148.

Singh S.D., Rao G.P. (2005): Stevia: the herbal sugar of $21^{\text {st }}$ century. Sugar Technology, 7(1): 17-24.

Srivastava S.P., Bhandari T.M.S., Yadav C.R., Joshi M., Erskine W. (2000): Boron deficiency in lentil: Yield loss and geographic distribution in a germplasm collection. Plant Soil, 219: 147-151.

Stephanie E.B., Svoboda V.P., Paul A.T., Marc W.V.I. (2005): Controlled drought affects morphology and anatomy of Salvia splendens. American Society for Horticultural Science, 130:775-781.

Tabrizian F., Osareh A.M. (2007): Improved seed emergence and yield related traits of marigold (Calendula offiinalis L.) by on-farm seed micronutrient treatment trials. Iranian J Crop Sci 9: 124- 141.

Tanaka M., Fujiwar T. (2008): Physiological roles and transport mechanisms of boron: perspectives from plants. Pflügers Arch. European J. Physiol. 456, 671-677. 